\title{
Temperature determines post-harvest quality of spinach leaves after gamma irradiation
}

\author{
Jin-Hong Kim*, Ji Hong Kim, Min Hee Lee, Jin Kyu Kim, and Byung Yeoup Chung* \\ Advanced Radiation Technology Institute, Korea Atomic Energy Research Institute, 29 Geumgu-gil, Jeongeup-si, \\ Jeollabuk-do 580-185, Republic of Korea
}

\begin{abstract}
The relative importance of radiation dose, storage time, and temperature in radiation processing of spinach (Spinacia oleracea L.), was evaluated in terms of the postharvest quality through a model study using leaf disks. Physiological activity and chlorophyll and carotenoid contents were measured to represent the postharvest quality (in terms of external appearance) of spinach, a leafy green vegetable. At $22^{\circ} \mathrm{C}$ and $30^{\circ} \mathrm{C}$, the higher gamma-radiation dose caused a greater decrease in the physiological activity, depending on the storage time of $4 \mathrm{~d}$. However, this decrease was not significant at $4^{\circ} \mathrm{C}$ and $15^{\circ} \mathrm{C}$. Total chlorophyll and carotenoid contents were substantially decreased by $3 \mathrm{kGy}$ at $15 \mathrm{oC}$, and dose-dependently by $0.5-3 \mathrm{kGy}$ at $22^{\circ} \mathrm{C}$. In contrast, the proportion of lutein in total carotenoid was significantly increased in the 2-3-kGy samples only at $22^{\circ} \mathrm{C}$, while that of $\beta$-carotene was slightly decreased, indicating progression of leaf aging. These data suggest that the unfavorable effect of gamma irradiation on the postharvest quality of spinach could be avoided or controlled by the storage time or temperature rather than the radiation dose. The current study could be available to improve radiation processing of other leafy green vegetables.
\end{abstract}

Ionizing radiation such as X-rays, gamma rays, and electron beams can be used to improve postharvest quality of fresh fruits and vegetables.1 Currently, a major use of irradiation to agricultural commodities is as a phytosanitary treatment to prevent the spread of invasive species and/or to overcome quarantine barrier to trade. ${ }^{2,3}$ In phytosanitary or postharvest irradiation treatments, researches have been focused on various factors affecting irradiation efficacy, such as low oxygen, dose rate, host, and temperature. ${ }^{2,4,5}$ Irradiation

*To whom correspondence should be addressed.

E-mail: bychung@kaeri.re.kr of various fresh-cut vegetables was effective to eliminate bacteria or human pathogens such as E.coli O157:H7, but it could cause a substantial loss of vitamin $\mathrm{C}$, depending on the vegetable, radiation dose, and storage time., ${ }^{4,6}$ This unfavorable effect of irradiation deteriorates the postharvest quality of vegetables. In case of leafy green vegetables such as spinach and lettuce, a change in chlorophyll and carotenoid contents affects the postharvest quality, associating with physiological activity or external appearance. Therefore, the object of this study is to reveal the relative importance of the radiation dose, storage time, and temperature in terms of the postharvest quality for radiation processing of spinach. We investigated postharvest physiological activities and photosynthetic pigment contents of spinach leaves for 4-d storage at different temperatures in darkness after gamma irradiation of $0.5,1,2$, and $3 \mathrm{kGy}$. The physiological activities and photosynthetic pigment contents were determined by chlorophyll fluorescence and HPLC analyses through a model study using leaf disks, respectively. ${ }^{7,8}$

In leafy green vegetables such as Romaine lettuce and spinach, the population of internalized Escherichia coli O157:H7 cells is reduced with a D10-value of 0.39 $\mathrm{kGy}$ or $0.27 \mathrm{kGy}$, respectively. ${ }^{9}$ Moreover, irradiation of electron beam with a dose above $1.07 \mathrm{kGy}$ eliminates E. coli $\mathrm{O} 157: \mathrm{H} 7$ and Salmonella from spinach leaves, but the respiration rate of spinach is not affected by irradiation up to $2.1 \mathrm{kGy}$, implying no product damage. ${ }^{10}$ To reveal the unfavorable effect of gamma irradiation on the postharvest quality of spinach, physiological activity of leaf disks was investigated during 4-d storage in darkness at 4, 15, 22 , or $30^{\circ} \mathrm{C}$ after irradiation with various doses from 0.5 to $3 \mathrm{kGy}$. Since spinach is a leafy green vegetable species, the physiological activity was estimated by a chlorophyll fluorescence parameter for 
photosynthetic activity (Fv/Fm) rather than the respiration rate previously used by Neal et al. ${ }^{10}$

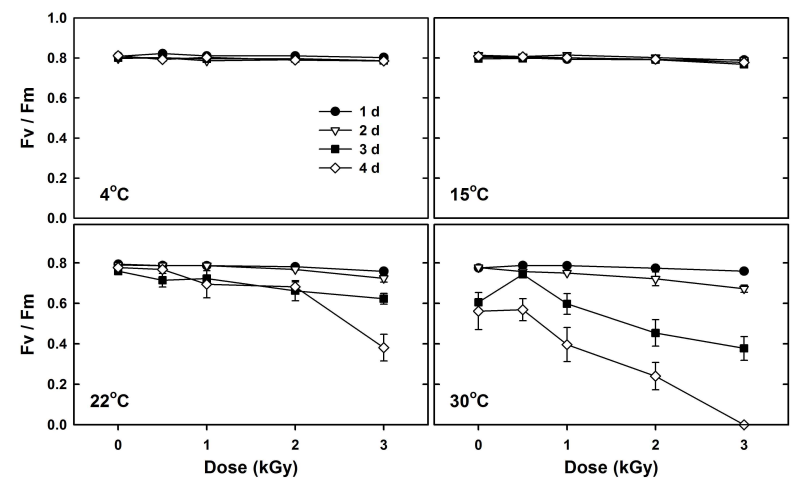

Figure 1. Change in physiological activity of the control and irradiated spinach leaves during the post-irradiation storage at different temperatures. Physiological activity was estimated by a chlorophyll fluorescence parameter for photosynthetic activity, the maximum photochemical efficiency of photosystem II or $\mathrm{Fv} / \mathrm{Fm}^{11}$ The optimal $\mathrm{Fv} / \mathrm{Fm}$ values for higher plants such as spinach are about 0.8. Bars represent means \pm S.E. $(\mathrm{n}=8)$.

The photosynthetic activity or physiological activity was kept constant in all the irradiated samples at $4^{\circ} \mathrm{C}$ and $15^{\circ} \mathrm{C}$, while it was significantly decreased depending on the radiation dose $(>1 \mathrm{kGy})$ and storage time $\left(>2 \mathrm{~d}\right.$ ) at $22^{\circ} \mathrm{C}$ and $30^{\circ} \mathrm{C}$ (Figure 1). This trend was clearly manifested as correlative visible damages as well as the lower physiological activity (Figure 2). These results suggest that postharvest irradiation of spinach with a dose of gamma rays above $1 \mathrm{kGy}$ should require stricter cold-chain storage.

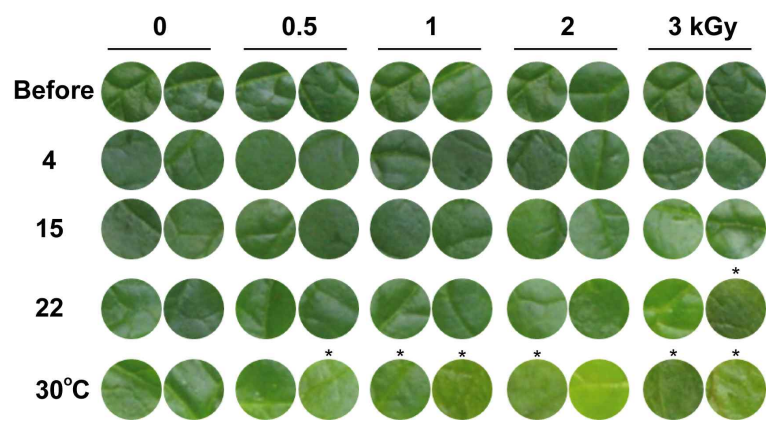

Figure 2. Dark-induced senescence of the control and irradiated leaves at different temperatures. Leaf disks were incubated in darkness for $4 \mathrm{~d}$ at $4,15,22$, or $30^{\circ} \mathrm{C}$, respectively. Asterisks represent decomposition of leaf tissues in spite of the relatively greenish leaf color.
Contents of chlorophylls and carotenoids are essentially associated with postharvest quality of leafy green vegetables after irradiation. Lester and Hallman reported that gamma irradiation at $2.0 \mathrm{kGy}$ significantly reduced carotenoids such as lutein/zeaxanthin, neoxanthin, violaxanthin, and $\beta$ -carotene as well as vitamin $\mathrm{C}$ in baby-leaf spinach. ${ }^{5}$ In the present study, total chlorophyll content in all the irradiated samples was maintained almost constant at $4{ }^{\circ} \mathrm{C}$ during the storage time of $4 \mathrm{~d}$, while it was significantly decreased by about $40 \%$ in the $3-\mathrm{kGy}$ sample at $15^{\circ} \mathrm{C}$ and by 18 to $52 \%$ in the $0.5-3-\mathrm{kGy}$ samples at $22^{\circ} \mathrm{C}$. This trend was also observed in the total carotenoid content, but less conspicuous. The proportion of lutein in total carotenoid or the ratio of lutein to total chlorophyll was significantly increased in the 2-3-kGy samples during the storage at $22^{\circ} \mathrm{C}$, but not at $4{ }^{\circ} \mathrm{C}$, while that of $\beta$-carotene was slightly decreased at both temperatures (Table 1). The increased lutein and decreased $\beta$-carotene in total carotenoid indicates progression of leaf senescence or aging. ${ }^{12}$ The dependence on the radiation dose and storage time has been shown for vitamin $\mathrm{C}$ loss of fresh-cut vegetables during the storage after gamma irradiation. ${ }^{4,6}$ Similarly, the present data demonstrate that both the radiation dose and storage time are main factors to affect the content and composition of chlorophylls and carotenoids in spinach after gamma irradiation, which are associated with the postharvest quality. Moreover, it is suggested that the unfavorable effect of gamma irradiation on the postharvest quality of spinach could be enhanced by the storage temperature.

Table 1. Change in proportion of $\beta$-carotene or lutein in total carotenoid during the storage at different temperatures after gamma irradiation

\begin{tabular}{|c|c|c|c|c|}
\hline \multirow{2}{*}{$\begin{array}{c}\text { Dose } \\
\text { (kGy) }\end{array}$} & \multicolumn{2}{|c|}{$\beta$-carotene $(\%)$} & \multicolumn{2}{|c|}{ Lutein $(\%)$} \\
\hline & $4^{\circ} \mathrm{C}$ & $22^{\circ} \mathrm{C}$ & $4^{\circ} \mathrm{C}$ & $22^{\circ} \mathrm{C}$ \\
\hline 0 & $19.0 \pm 0.7^{\mathrm{a}}$ & $16.8 \pm 1.2^{\mathrm{a}}$ & $41.4 \pm 0.1^{\mathrm{a}}$ & $44.4 \pm 0.8^{\mathrm{a}}$ \\
\hline 0.5 & $18.5 \pm 0.6^{\mathrm{a}}$ & $15.2 \pm 1.1^{\mathrm{a}}$ & $41.5 \pm 0.3^{\mathrm{a}}$ & $45.4 \pm 0.4^{\mathrm{a}}$ \\
\hline 1 & $18.3 \pm 0.6^{\mathrm{a}}$ & $16.0 \pm 1.0^{\mathrm{a}}$ & $41.5 \pm 0.4^{\mathrm{a}}$ & $46.7 \pm 0.9^{\mathrm{at}}$ \\
\hline 2 & $18.4 \pm 0.6^{\mathrm{a}}$ & $14.4 \pm 0.7^{\mathrm{a}}$ & $41.5 \pm 0.3^{\mathrm{a}}$ & $47.7 \pm 0.6^{\mathrm{b}}$ \\
\hline 3 & $17.8 \pm 0.5^{\mathrm{a}}$ & $13.8 \pm 0.6^{\mathrm{a}}$ & $41.3 \pm 0.1^{\mathrm{a}}$ & $50.0 \pm 0.8^{\mathrm{bc}}$ \\
\hline $\begin{array}{l}\text { Pared } \\
\text { t-test }\end{array}$ & ᄂ & \lrcorner & L & ل \\
\hline
\end{tabular}

Means in the same column followed by different letters are significantly different by a Student's t-test $(\mathrm{P}<0.05)$. Asterisks indicate significant differences between two groups $(\mathrm{P}<0.01)$. 
In conclusion, by the model study using spinach leaf disks, it was shown that gamma irradiation could affect the postharvest quality or physiological activity by reducing the contents of chlorophylls and carotenoids, or by modulating the composition of carotenoids. Despite any explicit limitations of this model study, the storage time, radiation dose, and temperature were found to be essential factors synergistically contributing to the unfavorable effect of gamma irradiation on the postharvest quality of spinach. The overall considerations about these factors will help to optimize the phytosanitary or postharvest irradiation treatments for leafy green vegetables.

KEYWORDS: Ionizing radiation; postharvest quality; storage temperature; carotenoid; chlorophyll; photosynthesis

Received March 14, 2014; Accepted March 30, 2014

\section{ACKNOWLEDGEMENT}

This research was supported by the Nuclear R \& D Program of the Ministry of Science, ICT and Future Planning (MSIP), Republic of Korea.

\section{REFERENCES AND NOTES}

1. Kader, A. A., Food Technol. 1986, 40(6), 117-121.

2. Hallman, G. J.; Lenvang-Brilz, N. M.; Zettler, J. L.; Winborne, I. C. J. Econ. Entomology. 2010, 103(6), 1950-1963.

3. Hallman, G. J. Radiat. Phys. Chem. 2012, 81, 861866.

4. Fan, X.; Sokorai, K. J. B. J. Food Sci. 2008, 73, S367-S372.

5. Lester, G. E.; Hallman, G. J.; Pérez, J. A. J. Agric. Food Chem. 2010, 58, 4901-4906.

6. Zhang, L.; Lu, Z.; Lu, F.; Bie, X. Food Control 2006, 17, 225-228.

7. Kim, J.-H.; Moon, Y. R.; Lee, M. H.; Kim, T. H.; Lee, J.-W.; Chung, B. Y. Kor. J. Hort. Sci. Technol. 2010, 28(1), 126-131.

8. Kim, J.-H.; Moon, Y. R.; Lee, M. H.; Kim, J. H.; Wi, S. G.; Park, B.-J.; Kim, C. S.; Chung, B. Y. J. Radiat. Res. 2011, 52, 441-449.

9. Niemira, B. A. J. Food Prot. 2007, 70, 2526-2532.

10. Neal, J. A.; Cabrera-Diaz, E.; Márquez-Gonzaález, M.; Maxim, J. E.; Castillo, A. J. Food Prot. 2008, 71, 2415-2420.

11. Krause, C. H; Weis, E. Annu. Rev. Plant Physiol. Plant Mol. Biol. 1991, 42, 313-349.

12. Lu, C.; Lu, Q.; Zhang, J.; Kuang, T. J. Exp. Bot. 2001, 52(362), 1805-1810. 